Article

\title{
Farmers' Criteria for Pesticide Selection and Use in the Pest Control Process
}

\author{
Mohammad Sharif Sharifzadeh 1,*, Gholamhossein Abdollahzadeh ${ }^{1}$, Christos A. Damalas ${ }^{2, *}$ (iD \\ and Rohollah Rezaei ${ }^{3}$ \\ 1 Department of Agricultural Extension and Education, Gorgan University of Agricultural Sciences and \\ Natural Resources, 4913815739 Gorgan, Iran; abdollahzade1@gmail.com \\ 2 Department of Agricultural Development, Democritus University of Thrace, GR-682 00 Orestiada, Greece \\ 3 Department of Agricultural Extension, Communication and Rural Development, Faculty of Agriculture, \\ University of Zanjan, 3879145371 Zanjan, Iran; r_rezaei@znu.ac.ir \\ * Correspondence: sharifsharifzadeh@gmail.com (M.S.S.); cdamalas@agro.duth.gr (C.A.D.); \\ Tel.: +30-25520-41116 (C.A.D.); Fax: +30-25520-41191 (C.A.D.)
}

Received: 30 December 2017; Accepted: 7 February 2018; Published: 12 February 2018

\begin{abstract}
Chemical pesticides have been widely overused by farmers in Iran, but farmers' criteria for pesticide selection and use are not well understood. A field survey of 411 farmers was carried out in Mazandaran, Iran, to study farmers' criteria for selecting and using pesticides in the pest control process and explaining differences in selection criteria among farmers. From a list with a total of 25 criteria, five main groups were identified as key decision criteria for pesticide selection and use, using factor analysis. These groups included: (i) performance and effectiveness criteria, (ii) awareness and information criteria, (iii) technical and operational criteria, (iv) environmental criteria, and (v) financial and accessibility criteria. Performance and effectiveness criteria had the highest importance for farmers when selecting and using pesticides (mean 3.45), followed by financial and accessibility criteria (mean 3.28). Farmers who received training regarding pesticide use (mean 2.23 vs. 1.90) and farmers who had experience with integrated pest management (IPM) practices (mean 2.46 vs. 1.79) tended to consider environmental criteria when selecting and using pesticides. Similarly, farmers who experienced health risks related to working with pesticides (mean $2.0 \mathrm{vs.} 1.77$ ), farmers who used protection when spraying (mean 2.58 vs. 1.87), and farmers who knew about natural enemies of pests (mean 2.11 vs. 1.85) tended to consider environmental criteria when selecting and using pesticides. Farmers without off-farm income tended to consider financial and accessibility criteria more than farmers with off-farm income (mean 3.40 vs. 3.18). Farmers with college education favored awareness and information criteria, whereas experienced farmers favored the criteria of performance and effectiveness. Farmers with a high income showed a tendency to prefer performance and effectiveness criteria more than farmers with less income. Farmers who thought that pesticides are hazardous preferred environmental criteria more than farmers who thought that pesticides are not hazardous. Farmers who believed in the effectiveness of alternatives to chemical pest control (e.g., use of biological control, pheromone traps, or cultural control) preferred performance and effectiveness criteria less than farmers who believed no effectiveness or slight effectiveness of alternatives to chemical pest control. The findings provide useful information for better understanding factors affecting farmers' choices of pesticides and for improving future extension courses related to farmers' decisions about pesticide use.
\end{abstract}

Keywords: pesticide dependency; pesticide selection; pest management; farmers' behaviour 


\section{Introduction}

Pesticides are a vital component and an integral part of modern agriculture [1,2]. These chemicals quickly gained great popularity as an efficient, labor-saving, and economic tool in pest management in most agricultural sectors [3]. They protect plants against harmful insects, fungi, and weeds, and also prevent some human diseases [4]. Over the last 60 years, farmers have achieved major progress in foodstuff production via the application of pesticides. Prevention or reduction of pest activities and agricultural losses at a reasonable cost improved crop yields and promoted food availability during all seasons. In certain cases, pesticides improved food nutritional value and safety $[5,6]$. Therefore, reliable and quality-improved agricultural produce at affordable prices to buyers and consequently great profits to farmers would be ensured by the essential role of pesticides. As a matter of fact, pesticides provide such benefits not only to farmers and consumers, but also to the whole society [7]. About 2.5 million tonnes (five billion pounds) of pesticides are used each year [8]. In other words, the most frequent method of managing pests and diseases in most agricultural sectors is through the application of pesticides [9]. Farmers depend heavily on pesticides [10], though several alternative strategies for pest management continue to evolve [11]. Despite the importance of pesticides and their wide use throughout the world, particularly in developing countries [10], there is very little evidence about pesticide use patterns for various pests and crops [12]. Farmers may be involved in pesticide overuse when trying to control different pests [13-15] because they often have limited information about pest occurrence and appropriate methods of control [12]. In fact, farmers may have different perceptions of pesticides [9] and, hence, they make their own decisions based on various factors and criteria $[9,16-20]$. Thus, understanding what actually drives farmers' voluntary self-behaviors in pesticide use would be an important issue [21] in an appropriate plan for promoting safe behavior in pesticide use.

A review of the literature indicates that farmers' beliefs about pesticide performance are one of the most important criteria for choosing and using pesticides [9,10,19,22-24]. If a pesticide does not have the necessary effectiveness to quickly kill the target pests, it may be less used by farmers or replaced by another pesticide. For example, Cameron [22] showed that the ineffectiveness of some earlier insecticide groups against key insect pests changed patterns of insecticide use. Conversely, effective pesticides that satisfy farmers are used in higher quantities [10]. Another criterion affecting the use of pesticides that has been considered in various studies is knowledge and information about the appropriate use of pesticides [13,19,20,25-27]. As highlighted by Mengistie et al. [19], smallholder farmers are mostly provided with too technical information on pesticides that are hazardous and involve a complex technology. Therefore, sufficient technical information on the correct application of pesticides is required to be delivered to smallholder farmers by various experts through agricultural extension services. Zyoud et al. [26] argued that farmers with good pesticide knowledge showed good practices in pesticide use and were more inclined to apply pesticides according to recommended guidelines for protective measures. Similarly, Chen et al. [13] revealed that the significant negative effect of pesticide overspray practiced by farmers can be reduced by improving their knowledge of pest management. In this research, a reduction of $10 \%-15 \%$ in farmers' overall use of pesticides was achieved via farmers' knowledge improvement. Similar findings have been reported by Idris et al. [17], Xu et al. [28], and Togbé et al. [29]. Technical and operational aspects are the other main criteria for pesticide use. Technical factors may constrain farmers to use alternative chemical pesticides [28]. Simply put, since technical constraints can lead to misapplication [29], farmers generally show a tendency to choose pesticides that can be more easily handled and applied. Moreover, farmers use those pesticides that can be combined with other pesticides, because they believe that a more effective action can result from pesticide mixtures [30].

To date, apart from surveys of farmers' perceptions, knowledge, and awareness regarding pesticide use and its impact, little research has been carried out on the nature of farmers' criteria for selecting and using pesticides, and whether these criteria follow similar patterns among farmers. Therefore, this research aimed to identify farmers' criteria for selecting and using pesticides in the 
pest control process. To achieve this goal, this study sets the following questions: (i) which criteria are important among farmers for selecting and using pesticides in the pest control process? and (ii) are there differences in farmers' criteria for using pesticides in the pest control process? Apart from providing a complete picture of farmers' criteria for pesticide use in the pest control process, the study aims to point out the role of farmers' attitude in pesticide use and assist future efforts to optimize the use of pesticides among farmers.

\section{Materials and Methods}

\subsection{Study Area}

Mazandaran Province of northern Iran was the area of the present study. This area is the most rainy and agriculturally productive province in Iran and was selected for the study because a large amount of the Iranian rice is produced in the area (39\% of the rice area, $42 \%$ of the rice production) and because chemical control is considered the most common viable option among farmers when an outbreak of pests occurs and also for the management of the most troublesome pest in the area, the Asiatic stem borer (Chilo suppressalis) [31]. Moreover, to analyze farmers' criteria about pesticide selection, it is necessary that farmers in the survey have the same understanding of the pest problems and the pesticides they require. An adequate description of the geographical features of this region and its farming systems can be found in Abdollahzadeh et al. [32]. In brief, the main crops grown in the province are: rice (the major rice-producing area of Iran), wheat, barley, fruits, and cotton. The total area under cultivation is 435,436 ha, almost $50 \%$ of which is covered by paddy rice according to Mazandaran Agri-Jihad Organization.

\subsection{Sampling and Data Collection}

Four hundred and twenty-five (425) rice farmers, recruited from their farms in Sari County, Mazandaran Province (population 20,636) in a rice belt area of northern Iran, participated in the study. However, due to a great extent of incomplete data in some questionnaires, 14 farmers were not included in the analyses, resulting in a sample of 411 farmers in the final analyses. Respondents came from different households. The sample selection followed a multi-stage sampling strategy. First, three districts, Markazi, Chahardangeh, and Dodangeh, were selected, as these three districts account for more than $50 \%$ of rice production in Sari County. Second, a total of six villages were randomly selected from each district to reflect potential differences in production technologies, integrated pest management (IPM) background, and pesticide use in rice. Finally, we randomly selected rice farmers (landholders) from the selected 18 villages. Face-to-face interviews were carried out with farmers in their farms using a standardized questionnaire and each interview took about $25 \mathrm{~min}$. The survey was administered in person by ten trained interviewers in the local language. Supervision and quality checks were made by the principal investigator. The main survey was conducted during the spring and summer of 2017.

\subsection{Questionnaire}

According to a literature review, we found only a few detailed studies related to farmers' criteria for selecting and using pesticides in the pest control process. Hence, the issue is still in an exploratory and premature stage. To identify the criteria items that farmers consider in selecting and using a pesticide product in the pest control operation, an expert panel discussion and a relevant literature survey were carried out $[9,19,22,25-27,29,33]$. The initial questionnaire items were first examined in three rounds by a panel organized by a plant protection professor, four local extension agents, and three researchers who majored in plant protection products, as well as five key informant farmers in pesticide use. Furthermore, three rounds of pre-survey testing with a week interval between testing periods were performed with 30 farmers out of the sample. All farmers in the pre-tests were asked if they fully understood the presented items. Accordingly, some items were modified to be more suitable for the local context and be more easily understood. The finalized questionnaire consisted of three 
parts: the first part targeted general information of the farmers and two subsequent parts followed; the second one was designed to capture the views of farmers on the experience of health risks related to working with pesticides in rice, IPM experience, perceptions of pesticide hazards, and perceptions of the effectiveness of pesticide alternatives, and the third one was designed to capture the importance of 25 criteria pertinent to pesticide use in the pest control process. Then, farmers were asked to indicate whether each of the identified criteria is important (on a five-point Likert-type scale from $1=$ not very important to $5=$ very important) when selecting and using a pesticide during the pest control process. All questions were related to common pesticides used in rice fields of the study area (e.g., cartap, fipronil, diazinon, fenitrothion, thiodicarb).

\subsection{Data Analysis}

Descriptive statistics (frequency distributions, percentages, means, and standard deviations) were calculated. Farmers' criteria for pesticide use in the pest control process were reduced to more manageable levels using factor analysis with a total of 25 individual criteria. Factor analysis is used to examine the underlying patterns for a large number of variables by defining sets of variables that are highly interrelated, known as factors [34]. In this study, principal components analysis was applied, using Varimax rotation, a cut-off point of 1 for eigenvalues, and factor loadings greater than 0.50. The Friedman's test was used to examine significant differences between the importance of each extracted factor related to farmers' criteria for pesticide use and rank factors in case of differences. In the final phase, one-way analysis of variance (ANOVA) was conducted. Statistically significant differences regarding farmers' criteria (extracted from factor analysis) according to socio-demographic characteristics of the respondents were assessed with the $t$-test, in the case of dichotomous socio-demographic variables. These variables included training regarding pesticide management, IPM experience, family labor force, self-consumption of product, experience of health risks related to working with pesticides, using protection when spraying, having off-farm income, and knowing about natural enemies of pests. In the case of variables measured on an interval scale, i.e., age, education level, farming experience, size of rice field, and annual farm income, statistically significance differences regarding farmers' criteria were tested through one-way ANOVA. The data that were obtained were entered and analyzed using the Statistical Package for Social Sciences (SPSS Version 19.0, SPSS Inc., Chicago, IL, USA). Differences among means were tested with the Fisher's least significant difference (LSD) post hoc test. A level of significance at $p<0.05$ was used for all statistical tests.

\section{Results}

\subsection{Sample Characteristics}

Table 1 presents the socio-economic characteristics of the farmers. A small proportion (16.1\%) of the farmers received training regarding pesticide management. Most farmers depended on pesticide use and $24.8 \%$ had experience with IPM practices. The majority of the farmers (84.9\%) did not use protection when spraying and working with pesticides. About half of the farmers (51.6\%) exploited family labor force in their fields and the majority (56.4\%) had no off-farm income. More than half of the farmers $(53.0 \%)$ reported self-consumption of the rice product. The majority of the farmers $(72.7 \%)$ did not experience health risks when working with pesticides and also a large proportion $(60.8 \%)$ did not know some natural enemies of pests located in their farms. The mean age of the farmers was 40.1 years and the largest proportion of the farmers (44.3\%) was in the age category $30-45$ years. Most farmers had a medium education level; $23.6 \%$ had no formal education at all, while $26.0 \%$ had an education of elementary or lower secondary school (between one and eight years of education). Some farmers $(17.0 \%)$ had some college degree (more than 12 years of education) and a considerable fraction (33.3\%) had completed high school (between eight and 12 years of education). Most farmers had high levels of farming experience (average 23.8 years); a large proportion (43.8\%) had farming 
experience that ranged between 15 and 25 years. Participants were all small-scale farmers for whom rice represented their staple crop. The land size under rice cultivation averaged 1.34 ha, but the majority of the farmers (47.2\%) had land of less than 1 ha. The average annual income from farming activities was 3865.7 US dollars; most farmers (44.5\%) were in the category 3000-6000 US dollars concerning annual income. The average rice yield was about 3.1 tonnes per ha; the majority of the farmers $(51.8 \%)$ were in the yield category of two to four tonnes per ha. Almost one fifth $(21.4 \%)$ of the farmers expressed the view that pesticides probably have no harmful effects (Table 2). A high proportion of the farmers (52.6\%) evaluated pesticides as slightly harmful, while $26.0 \%$ considered that pesticides have harmful effects. Regarding the effectiveness of alternative chemical pest control, the majority of the farmers (57.9\%) considered that the use of biological control, pheromone traps, or cultural control was not effective in decreasing crop damage by pests, while on the other hand, $10.7 \%$ of the farmers clearly expressed belief in the effectiveness of those alternatives of chemical pest control in the pest control process (Table 2).

Table 1. Descriptive characteristics of the farmers.

\begin{tabular}{|c|c|c|}
\hline Variable & Frequency & Percentage \\
\hline \multicolumn{3}{|c|}{ Received training regarding pesticide management $(N=405)$} \\
\hline No & 339 & 82.5 \\
\hline Yes & 66 & 16.1 \\
\hline \multicolumn{3}{|l|}{ IPM experience $(N=407)$} \\
\hline No & 305 & 74.2 \\
\hline Yes & 102 & 24.8 \\
\hline \multicolumn{3}{|l|}{ Family labor force $(N=411)$} \\
\hline No & 199 & 48.4 \\
\hline Yes & 212 & 51.6 \\
\hline \multicolumn{3}{|c|}{ Self-consumption of product $(N=411)$} \\
\hline No & 193 & 47.0 \\
\hline Yes & 218 & 53.0 \\
\hline \multicolumn{3}{|c|}{ Experience health risks related to working with pesticides $(N=410)$} \\
\hline No & 299 & 72.7 \\
\hline Yes & 111 & 27.0 \\
\hline \multicolumn{3}{|c|}{ Using protection when spraying $(N=405)$} \\
\hline No & 349 & 84.9 \\
\hline Yes & 56 & 13.6 \\
\hline \multicolumn{3}{|c|}{ Having off-farm income $(N=407)$} \\
\hline No & 232 & 56.4 \\
\hline Yes & 175 & 42.6 \\
\hline \multicolumn{3}{|c|}{ Knowing natural enemies to pests in the field $(N=406)$} \\
\hline No & 250 & 60.8 \\
\hline Yes & 156 & 38.0 \\
\hline \multicolumn{3}{|l|}{ Age $(N=407$, mean $=40.1)$} \\
\hline Less than 30 years & 97 & 23.6 \\
\hline From 30 to 45 years & 182 & 44.3 \\
\hline More than 45 years & 128 & 31.1 \\
\hline \multicolumn{3}{|l|}{ Education $(N=411)$} \\
\hline No education & 97 & 23.6 \\
\hline Elementary & 107 & 26.0 \\
\hline High school graduate & 137 & 33.3 \\
\hline Some college & 70 & 17.0 \\
\hline \multicolumn{3}{|c|}{ Farming experience $(N=411$, mean $=23.8)$} \\
\hline Less than 15 years & 93 & 22.6 \\
\hline From 15 to 25 years & 180 & 43.8 \\
\hline More than 25 years & 138 & 33.6 \\
\hline \multicolumn{3}{|c|}{ Size of rice field $(N=411$, mean $=1.34)$} \\
\hline Less than 1 ha & 194 & 47.2 \\
\hline From 1 to 2 ha & 182 & 44.3 \\
\hline More than 2 ha & 35 & 8.5 \\
\hline \multicolumn{3}{|c|}{ Annual farm income $(N=402$, mean $=\$ 3865.7)$} \\
\hline Less than $\$ 3000$ & 152 & 37.0 \\
\hline From $\$ 3000$ to $\$ 6000$ & 183 & 44.5 \\
\hline More than $\$ 6000$ & 67 & 16.3 \\
\hline \multicolumn{3}{|c|}{ Rice yield $(N=411$, mean $=3.1$ tonnes $/$ ha) } \\
\hline Less than 2 tonnes & 115 & 28.0 \\
\hline From 2 to 4 tonnes & 213 & 51.8 \\
\hline More than 4 tonnes & 83 & 20.2 \\
\hline
\end{tabular}

Percentages were calculated on the basis of the total number of respondents $(N=411)$. Number of responses lower than 411 is due to missing values. 
Table 2. Perceptions of pesticide hazards and effectiveness of pesticide alternatives among farmers.

\begin{tabular}{ccc}
\hline Perception & Frequency & Percentage \\
\hline Pesticide hazards & & \\
Not harmful & 88 & 21.4 \\
Slightly harmful & 216 & 52.6 \\
Harmful & 107 & 26.0 \\
\hline Effectiveness of pesticide & & \\
alternatives * & 238 & 57.9 \\
Not effective & 129 & 31.4 \\
Slightly effective & 44 & 10.7 \\
Effective & Biological control, pheromone traps, and cultural control.
\end{tabular}

* Biological control, pheromone traps, and cultural control.

\subsection{Farmers' Criteria for Pesticide Use in the Pest Control Process-Factor Analysis}

The value of Bartlett's test of sphericity was $6496.61(p<0.01)$, suggesting that the population correlation matrix is not an identity matrix. The Kaiser-Meyer-Olkin (KMO) measure of sampling adequacy in this research was 0.865 , confirming that the data were adequate for factor analysis (a value of 0.5 is generally considered acceptable). Table 3 shows the mean rating of each criterion. The top criteria identified were: pesticides that can kill all pests (mean 3.86), pesticides that kill only target pests (mean 3.64), affordability to use (mean 3.62), pesticides that kill pests quickly (mean 3.47), and observability of pesticide effectiveness (mean 3.35). The results of factor loadings, eigenvalues, and percentages of variance are summarized in Table 3. Five components with eigenvalues greater than 1 were extracted, which all together accounted for $68.47 \%$ of the total explained variation.

Factor 1 consisted of six items of the list and explained $16.13 \%$ of the total variance, with an eigenvalue 4.03 (Table 3). Based on the sub-items of the criteria list, factor 1 was termed 'performance and effectiveness criteria' because these items are related to expected effectiveness, which is one of the important causes leading to mass use of pesticides. Factor 2 consisted of six items that highlight the importance of an information source for farmers when selecting and using pesticide in the pesticide management process. Because these variables are directly related to the way of obtaining information about dosage, hazards, toxicity, and careful handling of pesticides by farmers, factor 2 was labeled 'awareness and information criteria' and accounted for $15.56 \%$ of the total variance, with an eigenvalue of 3.89. Factor 3 had six items, implying technical aspects of the proper usage of pesticides and spray techniques. Therefore, factor 3 was labeled 'technical and operational criteria'; it accounted for $14.56 \%$ of the total variance, with an eigenvalue of 3.64. Factor 4 included four items, highlighting the adverse health and environmental effects of pesticides, as well as the poisoning risk among farmers. Therefore, factor 4 was termed 'environmental criteria'; it accounted for $12.60 \%$ of the total variance, with an eigenvalue of 3.15. Factor 5 consisted of three items. Because these variables highlight the way of access and the importance of financial aspects for farmers when selecting and using pesticides, factor 5 was named 'financial and accessibility criteria' and accounted for $9.62 \%$ of the total variance, with an eigenvalue of 2.41. To verify reliability within factors, Cronbach's alpha was used [35]. All of the resulting five factors achieved a Cronbach's alpha value $>0.70$ (Table 3), with a reliability over 0.70 being the rule of thumb [35]. 
Table 3. Factor analysis for grouping pesticide selection criteria.

\begin{tabular}{|c|c|c|c|}
\hline Factor and Variable Description & Factor Loading & Mean & Rank \\
\hline \multicolumn{4}{|l|}{ Performance and effectiveness criteria (Eigenvalue: 4.03 ; Percent of variance: 16.13 ; Alpha $=0.86$ ) } \\
\hline Pesticide that kill only target pest & 0.773 & 3.64 & 2 \\
\hline Pesticide that can kill all pest & 0.830 & 3.86 & 1 \\
\hline Pesticide that kill the pest quickly & 0.713 & 3.47 & 4 \\
\hline Usability in several commonly cultivated crop on the farm & 0.733 & 3.24 & 6 \\
\hline Observability of pesticide effectiveness & 0.708 & 3.35 & 5 \\
\hline The required number of sprays per cropping season in order to destroy the target pest & 0.633 & 3.15 & 8 \\
\hline \multicolumn{4}{|l|}{ Awareness and information criteria (Eigenvalue: $3.89 ;$ Percent of variance: $15.56 ;$ Alpha $=0.83$ ) } \\
\hline Previous experience and knowledge with field survey & 0.605 & 2.91 & 10 \\
\hline Trust in manufacture brand & 0.635 & 2.55 & 12 \\
\hline According to other local extension agent recommendation & 0.838 & 2.34 & 15 \\
\hline According to other farmers recommendation & 0.891 & 2.36 & 14 \\
\hline According to other pesticide dealer recommendation & 0.773 & 2.84 & 11 \\
\hline Displayed necessary information and correct instructions for use on pesticide product labels & 0.718 & 2.08 & 17 \\
\hline \multicolumn{4}{|l|}{ Technical and operational criteria (Eigenvalue: 3.64 ; Percent of variance: $14.56 ;$ Alpha $=0.76$ ) } \\
\hline Legally approved pesticides & 0.628 & 1.88 & 22 \\
\hline Less pre-harvest interval & 0.636 & 1.86 & 23 \\
\hline Combinability with other pesticide & 0.772 & 1.82 & 25 \\
\hline Compatibility with existing farmer spraying equipment & 0.829 & 1.83 & 24 \\
\hline Amount of effort needed for calibrating the sprayer to apply the correct amount of pesticide & 0.576 & 2.09 & 16 \\
\hline Easy process of preparation for use & 0.813 & 2.38 & 13 \\
\hline \multicolumn{4}{|l|}{ Environmental criteria (Eigenvalue: 3.15; Percent of variance: $12.60 ;$ Alpha $=0.76$ ) } \\
\hline Decompose rapidly into harmless compounds & 0.507 & 1.94 & 20 \\
\hline Low adverse environmental effects & 0.901 & 2.03 & 18 \\
\hline Possibility of pest resistance and increasing the dose in the next use & 0.911 & 1.91 & 21 \\
\hline Low risk of poisoning during handling & 0.896 & 1.96 & 19 \\
\hline \multicolumn{4}{|l|}{ Financial and accessibility criteria (Eigenvalue: 2.41 ; Percent of variance: $9.62 ;$ Alpha $=0.72$ ) } \\
\hline Convenient accessibility (supplied by local dealers) & 0.748 & 3.20 & 7 \\
\hline Affordability to use & 0.868 & 3.62 & 3 \\
\hline Possibility to buy with discounts price & 0.805 & 3.02 & 9 \\
\hline
\end{tabular}

\subsection{Factors Ranking}

The Friedman's test was used to examine significant differences between the importance of each factor and rank them if there was a difference. Table 4 shows that the significance of the factors studied varied significantly in the opinion of farmers $(p<0.05)$. Therefore, the ranks of extracted factors were not equal. As shown in Table 4, in descending order, performance and effectiveness criteria (mean 4.19), financial and accessibility criteria (mean 3.86), awareness and information criteria (mean 2.91), environmental criteria (mean 2.03), and technical and operational criteria (mean 2.00) had the highest importance for farmers when selecting and using pesticides.

Table 4. Freidman test for ranking extracted factors (groups) of pesticide selection criteria.

\begin{tabular}{ccccc}
\hline Extracted Factor & Friedman Mean Rank & Mean & Std. & Rank \\
\hline $\begin{array}{c}\text { Performance and } \\
\text { effectiveness factors } \\
\text { Awareness and } \\
\text { information factors } \\
\quad \begin{array}{l}\text { Technical and } \\
\text { operational factors } \\
\text { Environmental } \\
\quad \text { factors }\end{array}\end{array}$ & 4.19 & 3.45 & 0.81 & 1 \\
$\begin{array}{c}\text { Financial and } \\
\text { accessibility factors }\end{array}$ & 2.91 & 2.51 & 1.04 & 3 \\
\hline
\end{tabular}

Chi-Square: 692.31, Significance: 0.00, Std: standard deviation.

\subsection{Factors Associated with Farmers' Criteria for Pesticide Use}

Farmers who received training regarding pesticide management (mean 2.23, $p<0.05$ ), farmers who had experience with IPM practices (mean 2.46, $p<0.01$ ), farmers who experienced health risks related to working with pesticides (mean 2.03, $p<0.05$ ), farmers who used protection when spraying (mean 2.58, 
$p<0.01$ ), and farmers who knew about natural enemies of pests in the field (mean 2.11, $p<0.05$ ) tended to consider 'environmental criteria' when selecting and using pesticides. An examination of having off-farm income revealed that farmers who did not have off-farm income tended to consider 'financial and accessibility criteria' more than farmers who had off-farm income (mean 3.40, $p<0.05$ ). There were no significant differences in farmers' criteria for pesticide use in the pest control process with regard to family labor force and self-consumption of the product (Table 5).

Table 5. Effect of farmers' socio-demographic characteristics on pesticide selection criteria ( $t$-test results).

\begin{tabular}{|c|c|c|c|c|c|}
\hline $\begin{array}{c}\text { Socio-Demographic } \\
\text { Variable }\end{array}$ & $\begin{array}{l}\text { Performance and } \\
\text { Effectiveness } \\
\text { Criteria }\end{array}$ & $\begin{array}{l}\text { Awareness and } \\
\text { Information } \\
\text { Criteria }\end{array}$ & $\begin{array}{l}\text { Technical and } \\
\text { Operational } \\
\text { Criteria }\end{array}$ & $\begin{array}{l}\text { Environmental } \\
\text { Criteria }\end{array}$ & $\begin{array}{c}\text { Financial and } \\
\text { Accessibility } \\
\text { Criteria }\end{array}$ \\
\hline & Mean & Mean & Mean & Mean & Mean \\
\hline \multicolumn{6}{|l|}{$\begin{array}{l}\text { Received training } \\
\text { regarding pesticide } \\
\text { management }\end{array}$} \\
\hline No & 3.45 & 2.49 & 1.95 & 1.90 & 3.29 \\
\hline Yes & 3.44 & 2.61 & 2.13 & 2.23 & 3.23 \\
\hline$t$-test & $0.12 \mathrm{~ns}$ & $-0.78 \mathrm{~ns}$ & $-1.65 \mathrm{~ns}$ & $-2.38 *$ & $0.45 \mathrm{~ns}$ \\
\hline \multicolumn{6}{|l|}{ IPM experience } \\
\hline No & 3.47 & 2.53 & 1.98 & 1.79 & 3.26 \\
\hline Yes & 3.38 & 2.46 & 1.96 & 2.46 & 3.31 \\
\hline$t$-test & $0.95 \mathrm{~ns}$ & $0.65 \mathrm{~ns}$ & $0.24 \mathrm{~ns}$ & $-5.76^{* *}$ & $-0.39 \mathrm{~ns}$ \\
\hline \multicolumn{6}{|l|}{ Family labor force } \\
\hline No & 3.46 & 2.48 & 1.94 & 1.98 & 3.28 \\
\hline Yes & 3.43 & 2.59 & 2.08 & 1.91 & 3.24 \\
\hline$t$-test & $0.31 \mathrm{~ns}$ & $-0.93 \mathrm{~ns}$ & $-1.57 \mathrm{~ns}$ & $0.63 \mathrm{~ns}$ & $0.38 \mathrm{~ns}$ \\
\hline \multicolumn{6}{|l|}{$\begin{array}{l}\text { Self-consumption } \\
\text { of product }\end{array}$} \\
\hline No & 3.41 & 2.43 & 1.99 & 1.95 & 3.24 \\
\hline Yes & 3.48 & 2.59 & 1.97 & 1.97 & 3.31 \\
\hline$t$-test & $-0.88 \mathrm{~ns}$ & $-1.56 \mathrm{~ns}$ & $0.26 \mathrm{~ns}$ & $-0.24 \mathrm{~ns}$ & $-0.72 \mathrm{~ns}$ \\
\hline \multicolumn{6}{|c|}{$\begin{array}{l}\text { Experience health risks } \\
\text { related to working } \\
\text { with pesticides }\end{array}$} \\
\hline No & 3.47 & 2.51 & 1.94 & 1.77 & 3.27 \\
\hline Yes & 3.40 & 2.52 & 2.08 & 2.03 & 3.32 \\
\hline$t$-test & $0.69 \mathrm{~ns}$ & $-0.38 \mathrm{~ns}$ & $-1.52 \mathrm{~ns}$ & $-2.49 *$ & $-0.45 \mathrm{~ns}$ \\
\hline \multicolumn{6}{|l|}{$\begin{array}{l}\text { Use protection } \\
\text { when spraying }\end{array}$} \\
\hline No & 3.45 & 2.53 & 2.01 & 1.87 & 3.25 \\
\hline Yes & 3.47 & 2.45 & 1.78 & 2.58 & 3.46 \\
\hline$t$-test & $-0.16 \mathrm{~ns}$ & $0.62 \mathrm{~ns}$ & $1.76 \mathrm{~ns}$ & $-4.12^{* *}$ & $-0.16 \mathrm{~ns}$ \\
\hline \multicolumn{6}{|c|}{ Having off-farm income } \\
\hline No & 3.46 & 2.55 & 1.99 & 1.96 & 3.40 \\
\hline Yes & 3.44 & 2.47 & 1.96 & 1.94 & 3.18 \\
\hline$t$-test & $0.25 \mathrm{~ns}$ & $0.75 \mathrm{~ns}$ & $0.31 \mathrm{~ns}$ & $0.21 \mathrm{~ns}$ & $2.25 *$ \\
\hline \multicolumn{6}{|c|}{$\begin{array}{l}\text { Knowing natural enemies } \\
\text { of pests in the field }\end{array}$} \\
\hline No & 3.44 & 2.50 & 1.95 & 1.85 & 3.26 \\
\hline Yes & 3.47 & 2.54 & 2.01 & 2.11 & 3.27 \\
\hline$t$-test & $-0.46 \mathrm{~ns}$ & $-0.37 \mathrm{~ns}$ & $-0.63 \mathrm{~ns}$ & $-2.40 *$ & $-0.11 \mathrm{~ns}$ \\
\hline
\end{tabular}

* Significant at $p<0.05,{ }^{* *}$ significant at $p<0.01$, ns: not significant.

The one-way ANOVA revealed significant differences $(p<0.05)$ among education groups with regard to farmers' criteria for pesticide use in the pest control process (Table 6). Farmers with college education (mean 2.99) tended to prefer 'awareness and information criteria' more than farmers with less education. A wider difference among the different farming experience groups for 'performance and effectiveness criteria' was detected $(p<0.01)$. Highly experienced farmers (mean 3.85) favored 
'performance and effectiveness criteria' for pesticide use in the pest control process. Farmers' criteria regarding 'performance and effectiveness criteria' for pesticide use also varied significantly across different income groups $(p<0.01)$. Farmers with an income of more than 6000 US dollars (mean 3.74) showed a tendency to prefer 'performance and effectiveness criteria' more than farmers with an income of less than 6000 US dollars. There were no significant differences in farmers' criteria for pesticide use in the pest control process with regard to age, size of rice field, and rice yield (Table 6).

Table 6. Effect of farmers' socio-demographic characteristics on pesticide selection criteria (ANOVA results).

\begin{tabular}{|c|c|c|c|c|c|}
\hline $\begin{array}{l}\text { Socio-Demographic } \\
\text { Variable }\end{array}$ & $\begin{array}{l}\text { Performance and } \\
\text { Effectiveness } \\
\text { Criteria }\end{array}$ & $\begin{array}{l}\text { Awareness and } \\
\text { Information } \\
\text { Criteria }\end{array}$ & $\begin{array}{l}\text { Technical and } \\
\text { Operational } \\
\text { Criteria }\end{array}$ & $\begin{array}{c}\text { Environmental } \\
\text { Criteria }\end{array}$ & $\begin{array}{c}\text { Financial and } \\
\text { Accessibility } \\
\text { Criteria }\end{array}$ \\
\hline & Mean & Mean & Mean & Mean & Mean \\
\hline \multicolumn{6}{|l|}{ Age } \\
\hline Less than 30 years & 3.49 & 2.33 & 2.03 & 1.93 & 3.30 \\
\hline From 30 to 45 years & 3.45 & 2.59 & 1.96 & 1.87 & 3.21 \\
\hline More than 45 years & 3.44 & 2.53 & 1.94 & 2.09 & 3.34 \\
\hline$F$-test & $0.12 \mathrm{~ns}$ & $2.06 \mathrm{~ns}$ & $0.37 \mathrm{~ns}$ & $1.83 \mathrm{~ns}$ & $0.68 \mathrm{~ns}$ \\
\hline \multicolumn{6}{|l|}{ Education } \\
\hline No education & 3.36 & 2.27 (a) & 1.98 & 1.75 & 3.28 \\
\hline Elementary & 3.49 & 2.32 (a) & 1.93 & 1.95 & 3.29 \\
\hline $\begin{array}{l}\text { High school } \\
\text { graduate }\end{array}$ & 3.47 & 2.59 (a) & 1.99 & 2.01 & 3.23 \\
\hline Some college & 3.47 & $2.99(b)$ & 2.02 & 2.16 & 3.35 \\
\hline$F$-test & $0.56 \mathrm{~ns}$ & $8.40^{* *}$ & $0.19 \mathrm{~ns}$ & $2.38 \mathrm{~ns}$ & $0.24 \mathrm{~ns}$ \\
\hline \multicolumn{6}{|l|}{ Farming experience } \\
\hline Less than 15 years & 2.81 (a) & 2.53 & 1.84 & 1.82 & 3.29 \\
\hline From 15 to 25 years & 3.47 (b) & 2.54 & 2.02 & 1.99 & 3.24 \\
\hline More than 25 years & $3.85(\mathrm{c})$ & 2.46 & 2.01 & 2.02 & 3.33 \\
\hline$F$-test & $58.22 * *$ & $0.30 \mathrm{~ns}$ & $1.56 \mathrm{~ns}$ & $1.20 \mathrm{~ns}$ & $0.32 \mathrm{~ns}$ \\
\hline \multicolumn{6}{|l|}{ Size of rice field } \\
\hline Less than 1 ha & 3.49 & 2.60 & 1.98 & 2.08 & 3.25 \\
\hline From 1 to 2 ha & 3.42 & 2.40 & 1.96 & 1.83 & 3.28 \\
\hline More than 2 ha & 3.36 & 2.59 & 2.09 & 1.96 & 3.45 \\
\hline$F$-test & $0.61 \mathrm{~ns}$ & $1.78 \mathrm{~ns}$ & $0.40 \mathrm{~ns}$ & $2.88 \mathrm{~ns}$ & $0.64 \mathrm{~ns}$ \\
\hline \multicolumn{6}{|l|}{ Annual farm income } \\
\hline Less than $\$ 3000$ & 3.34 (a) & 2.40 & 1.86 & 1.86 & 3.35 \\
\hline From $\$ 3000$ to $\$ 6000$ & $3.43(\mathrm{a})$ & 2.63 & 2.02 & 2.04 & 3.24 \\
\hline More than $\$ 6000$ & $3.74(\mathrm{~b})$ & 2.45 & 2.11 & 1.95 & 3.21 \\
\hline$F$-test & $5.87^{* *}$ & $2.27 \mathrm{~ns}$ & $2.79 \mathrm{~ns}$ & $1.36 \mathrm{~ns}$ & $0.73 \mathrm{~ns}$ \\
\hline \multicolumn{6}{|l|}{ Rice yield } \\
\hline Less than 2 tonnes & 3.42 & 2.48 & 2.03 & 1.81 & 3.35 \\
\hline From 2 to 4 tonnes & 3.47 & 2.47 & 2.00 & 1.97 & 3.18 \\
\hline More than 4 tonnes & 3.42 & 2.68 & 1.84 & 2.14 & 3.44 \\
\hline$F$-test & $0.22 \mathrm{~ns}$ & $1.22 \mathrm{~ns}$ & $1.36 \mathrm{~ns}$ & $2.48 \mathrm{~ns}$ & $2.50 \mathrm{~ns}$ \\
\hline
\end{tabular}

** Significant at $p<0.01$, ns: not significant. Different letters within each variable indicate statistically significant differences.

The importance of 'environmental criteria' for pesticide use in the pest control process varied significantly with farmers' perceptions of pesticide hazard $(p<0.01)$ (Table 7). Farmers who thought of pesticides as harmful (mean 2.17) or slightly harmful substances (mean 1.97) preferred 'environmental criteria' more than farmers who thought that pesticides are not harmful (mean 1.68). Farmers who believed in the effectiveness of alternatives to chemical pest control (i.e., biological control, pheromone traps, or cultural control) (mean 2.84) preferred 'performance- effectiveness criteria' less than farmers who believed no effectiveness (mean 3.53) or slight effectiveness of alternatives to chemical pest control (mean 3.50). 
Table 7. Effect of farmers' perceptions of pesticide hazards and effectiveness of pesticide alternatives on pesticide selection criteria (ANOVA results).

\begin{tabular}{cccccc}
\hline Perception & $\begin{array}{c}\text { Performance and } \\
\text { Effectiveness } \\
\text { Criteria }\end{array}$ & $\begin{array}{c}\text { Awareness and } \\
\text { Information } \\
\text { Criteria }\end{array}$ & $\begin{array}{c}\text { Technical and } \\
\text { Operational } \\
\text { Criteria }\end{array}$ & $\begin{array}{c}\text { Environmental } \\
\text { Criteria }\end{array}$ & $\begin{array}{c}\text { Financial and } \\
\text { Accessibility } \\
\text { Criteria }\end{array}$ \\
\hline Mean & Mean & Mean & Mean & Mean \\
\hline $\begin{array}{c}\text { Pesticide hazards } \\
\text { perception }\end{array}$ & & & & \\
\hline Not harmful & 3.41 & 2.48 & 1.98 & $1.68(\mathrm{a})$ & 3.31 \\
Slightly harmful & 3.43 & 2.46 & 2.00 & $1.97(\mathrm{~b})$ & 3.18 \\
Harmful & 3.52 & 2.66 & 1.92 & $2.17(\mathrm{~b})$ & 3.45 \\
F-test & $0.66 \mathrm{~ns}$ & $1.37 \mathrm{~ns}$ & $0.34 \mathrm{~ns}$ & $5.69^{* *}$ & $2.84 \mathrm{~ns}$ \\
\hline Effectiveness of & & & & & \\
pesticide alternatives & & & & & \\
\hline Not effective & $3.53(\mathrm{a})$ & 2.57 & 1.99 & 2.05 & 3.28 \\
Slightly effective & $3.50(\mathrm{a})$ & 2.37 & 2.03 & 1.84 & 3.25 \\
Effective & $2.84(\mathrm{~b})$ & 2.65 & 1.76 & 1.82 & 3.39 \\
F-test & $15.05 * *$ & $1.93 \mathrm{~ns}$ & $1.88 \mathrm{~ns}$ & $2.20 \mathrm{~ns}$ & $0.33 \mathrm{~ns}$ \\
\hline
\end{tabular}

** Significant at $p<0.01, \mathrm{~ns}$ : not significant. Different letters $(\mathrm{a}, \mathrm{b})$ within each variable indicate statistically significant differences.

\section{Discussion}

In this paper, we explored rice farmers' criteria for pesticide selection and use in the pest control process using data from a survey conducted in Sari County of Mazandaran Province, Iran. Five factors: performance and effectiveness criteria, awareness and information criteria, technical and operational criteria, environmental criteria, and financial affordability and accessibility criteria, were identified as key decision criteria for farmers' pesticide selection and use. According to Rational Choice Theory (RCT) or Rational Action Theory (RAT), farmers will seek pesticides that are easily accessible at reasonable prices besides having the benefits of appropriate performance and effectiveness for pest management [36]. This was confirmed by the results of this research, in which the criteria related to performance and effectiveness, as well as the criteria related to financial affordability and accessibility, had the highest ranks among factors. Since farmers' main objectives for using pesticides as a quick and easy solution to pest control [37] are crop protection and farm yield enhancement, the factors of performance and effectiveness are the main determinants of farmers' decisions in selecting and using pesticides, as also suggested by previous related studies [9,10,19,22-24]. Obviously, the studied farmers were seeking to use the least amount of pesticides that could quickly and visibly kill major target pests in their crops during the cropping season with minimized possible damages.

The findings appear to be in line with those of previous studies, highlighting the importance of financial affordability and accessibility when selecting and using pesticides in the process of pest control $[18,19,23,38]$. As mentioned above, the consideration of pesticide prices is a regular practice among farmers in developing countries [33,39]. In fact, the driving force behind farmers' decisions in choosing pesticides is the economic motivation [38]. The significance of this issue was doubled when more than half of the farmers in this study had no off-farm income and more than $90 \%$ of them had a farmland area of less than 1 or 2 ha. Also, it is worth mentioning that until 2009, the Iranian government supported farmers through subsidies on fertilizers, pesticides, and fuel, and therefore, pesticides were easily available to farmers at low prices [40]. However, in light of a new policy of economic adjustment, the government cut those subsidies after 2009, which led farmers to alternative methods of pest control beyond pesticides, such as biological control agents [41]. Under such circumstances, farmers were more sensitive to pesticide product prices as the main factor affecting their selection and use of pesticides. Furthermore, the results are indicative of the lowest ranks of technical and operational factors, which implied a lower importance in farmers' decisions about pesticide use and reflected a traditional action. Pesticides are toxic and hazardous and involve a complex technology [19], while farmers in developing countries, like Iran, have limited 
knowledge of using pesticides in suitable amounts [23,41,42] due to their low levels of education and lack of training in pesticide management. As a result, farmers rely on their own experience when choosing and using different types of pesticides $[43,44]$ and often ignore relevant technical criteria and recommendations [44].

Farmers who received training on pesticide management tended to prefer environmental criteria as compared to those farmers who did not receive training. As Talukder et al. [45] stressed, this may be due to the high awareness of educated farmers of the harmful effects of pesticides on the environment. Education and training were the main determinants of environmentally sound behavior in pest control, in the sense that high levels of education and training appeared to discourage pesticide use [46]. Contrary to the expectations, the observed difference between the two groups of farmers was not significant in this study, in terms of technical and operational criteria. This result might be explained by the ineffectiveness of training courses to create significant changes in farmers' levels of technical knowledge and information. Accordingly, it is necessary to revise the curricula of these courses and provide more relevant contents, so as to increase farmers' knowledge and skills concerning correct application of pesticides by carefully assessing farmers' needs.

Farmers with IPM experience considered the environmental criteria in their choice and use of pesticides as compared to those farmers who lacked any IPM experience. Plianbangchang et al. [25] and Alam et al. [47] emphasized that IPM, as an ecological method and environmentally friendly technology, is a multi-faceted approach to pest management that seeks to minimize the negative impacts on the environment. Therefore, it is evident that farmers with IPM experience consider environmental criteria more important when selecting and using pesticides. Farmers who faced health risks related to working with pesticides showed a tendency to prefer environmental criteria when using pesticides compared to those farmers who did not have such experience. In this respect, according to the Health Belief Model (HBM) presented by Rosenstock [48], the more a farmer experiences health risks and threats of pesticides and the more he/she believes that he/she is seriously exposed to pesticide-related risks (i.e., perceived severity of threat and perceived susceptibility), the more likely he/she is to show safe behaviors in pesticide use, related to environmental conservation. Similarly, farmers who took protection when spraying pesticides preferred the environmental criteria more than those farmers who did not take protection. This result may be explained by the fact that the improper use of pesticides leads to environmental and health risks all over the world, especially in developing countries [49], while performing safety measures, like using protective equipment, can reduce these hazards [50,51]. In this regard, Sharifzadeh et al. [52] highlighted that the use of protection equipment increases farmers' safety behaviors and is effective in avoiding pesticide-related health and environmental risks.

Farmers with off-farm income tended to prefer the criteria of financial affordability and accessibility when using pesticides as compared to those farmers who did not have off-farm income. It could be deemed that farmers with no off-farm income decide to choose and use costly pesticides more hesitantly due to their limited sources of income and possibly due to low financial power and a lack of government support of agricultural input subsidies, including pesticides. In fact, farmers in developing countries, particularly in Iran, first consider pesticide prices before buying and using them [32]. This is true for farmers who do not have an off-farm income, since they are more sensitive to the financial criteria mainly caused by an insufficient farm income, compared to other farmers. Based on the environmental criteria for using pesticides, the significant difference between farmers who had familiarity with the natural enemies of pests and those who were unfamiliar could be attributed to the fact that knowing natural enemies of pests is a proxy indicator of farmers' ecological literacy, which leads to environmentally friendly behaviors. Farmers with college education tended to consider awareness and information criteria for using pesticides more than those with less education. This result might be explained by the fact that educated farmers are aware of the importance of technical information concerning the pest control process and feel they further require to meet their information needs. Accordingly, these farmers try to make better and more accurate decisions regarding the use of pesticides based on the information and awareness criteria and obtain 
the necessary information from various channels and resources, such as local extension agents, experts, and other farmers. Farmers with more farming experience had a tendency to further regard the criteria of performance and effectiveness compared to those farmers with less farming experience. In fact, due to a better understanding of pests and pesticides, a more experienced farmer may decide to use pesticide products that show adequate effectiveness on more pests when used in minimum quantities.

Farmers with a high annual farm income did not tend to consider the performance and effectiveness criteria when using pesticides compared to those farmers who had a lower annual farm income. Damalas and Koutroubas [24] and Oluwole and Cheke [33] emphasized pesticide effectiveness and price as two key factors affecting pesticide purchases and applications. It seems that farmers with a higher financial and purchasing power prefer to use pesticides with high effectiveness in controlling pests, regardless of products prices. On the other hand, since the use of pesticides with high effectiveness leads to enhanced farm yields by reducing pest prevalence and subsequent damage to crops, farmers with a high annual farm income consider pesticide effectiveness as the most important criterion for selecting and using them and try to augment their income by taking this approach. Farmers who thought that pesticides have risk preferred environmental criteria more than those farmers who did not have such a perception. One possible explanation for this finding might be that the perception of pesticide hazards is a relative indicator of farmers' environmental concerns. Farmers were probably more aware of the risks of using pesticides and thus gave high priority to the environmental criteria when choosing and using pesticide products. Accordingly, a main policy option should be based on the upgrade of the extension services with additional training on the hazardous nature of pesticides and provision with knowledge about pesticide use. In this regard, verbal recommendations, extension brochures and bulletins, fact sheets, posters, and videos can provide some ways of making farmers aware of the dangers of such chemicals, so as to adopt the necessary safety measures when dealing with them. Farmers who did not know about effective alternatives to chemical pest control had a greater tendency to consider the criteria of effectiveness and performance compared to those farmers who believed in the effectiveness of alternatives to chemical pest control. Obviously, farmers who were not aware of the benefits of pesticide alternatives and believed that these alternatives cannot provide the necessary effectiveness for managing pests supposed the use of pesticides as the best way to control pests and thus sought to select and use those with high effectiveness for pest management. As Hashemi and Damalas [9] discussed, such farmers did not seem to believe in IPM principles and had a tendency to increase their use of pesticides every year. In contrast, farmers who considered pesticides as effective alternatives for pest control showed less preference for performance and effectiveness criteria when using pesticides, because they presumed that pesticide use was one of the methods of pest control and its effectiveness depended on using it along with other methods (e.g., IPM). Therefore, it is necessary for farmers to be provided with the right information. In conclusion, the importance of using suitable pesticides with maximum benefits by farmers should be emphasized through large-scale training and community awareness programs, particularly with the help of mass media, such as radio and television.

As the use of synthetic pesticides by farmers has direct effects on the environment and excessive reliance on them poses various threats to the environment and health effects on farmers [53], environmental aspects have been considered as another main factor influencing farmers' use of pesticides $[16,33]$. Nevertheless, evidence from different studies suggests that farmers are aware of the environmental hazards of overusing pesticides [16,32,54], but they are sometimes unable to translate this awareness into their practices $[55,56]$. Chemical pesticides are currently the cheapest and most effective means of pest control in the short run [25]. It is becoming difficult to have high productivity on many farms without pesticides. This is the reason for the wide use of different types of pesticides. Finally, in addition to the mentioned criteria, another main determinant of pesticide use is farmers' accessibility to pesticides and their financial ability to buy them $[18,19,22,23,37]$. In this regard, Mengistie et al. [19] emphasized that farmers' choices of pesticides are directly affected by pesticide availability and marketing. Therefore, pesticide selection can be largely explained by some structural 
features of the pesticide market. The more pesticides are readily available to farmers, the more likely farmers will use them. On the other hand, most farmers, particularly small-scale farmers, select pesticides according to product prices. In fact, farmers' consideration of pesticide prices is a regular practice in developing countries $[33,38]$. In this respect, findings obtained by Ngowi et al. [23] indicated that increasing pesticide prices is one of the main reasons for the decreasing trend of pesticide use. Therefore, the prices of pesticides and farmers' financial abilities to buy them have clear effects on their pesticide use patterns [37].

\section{Conclusions, Limitations, and Future Perspectives}

This research presented rice farmers' criteria for pesticide use as a multi-dimensional concept in the pest control process in Sari County of Mazandaran Province, Iran. A specific set of farmers' criteria for selecting and using pesticides was highlighted. Performance and effectiveness criteria had the highest importance for farmers when selecting and using pesticides, followed by financial and accessibility criteria. The research then showed that there is a statistically significant relationship between each of the five groups of criteria and various socio-economic characteristics of farmers. The findings provide useful information for better understanding factors affecting farmers' choices of pesticides and for improving future extension courses related to farmers' decisions about pesticide use. Providing suitable information, as well as technical and operational support, is more under the control of extension services. The reported research has some limitations that are worth mentioning. First, the use of cross-sectional data prevents examination of the evolution in changes of farmers' criteria for pesticide use in pest management practices. Second, our sample includes resource poor farmers who often welcome the most available method of pest control, such as chemical control. In order to partially resolve this bias, future research should try to include different groups of farmers. Third, the empirical study has focused specifically on Iranian rice farmers, so the results obtained here may not be entirely generalizable to other cropping systems or countries. Our study opens up opportunities for further research. First, future studies might examine the relationships among the five criteria-factors and their importance for different crops using structural equation modeling instead of means comparison analysis. Further research could use a qualitative approach to better understand the importance of these criteria dimensions for farmers in different areas. Also, widening the sample to incorporate the views of extension agents, crop protection experts, pesticides retailers, and pesticide producers-companies will not only lead to a gain of managerial views, but will also help actors in the supply chain of pesticides reach a real understanding of each other's needs.

Author Contributions: M.S.S. contributed to the formulation of the questionnaire items and design of the research scenario, as well as data collection; G.A. contributed to data analysis, as well as reviewing the literature; C.A.D. and R.R. wrote and edited the article. All authors approved the final version of this article.

Conflicts of Interest: The authors declare no conflict of interest.

\section{References}

1. Narita, K.; Matsui, Y.; Iwao, L.; Kamata, M.; Matsushita, T.; Shirasaki, N. Selecting pesticides for inclusion in drinking water quality guidelines on the basis of detection probability and ranking. Environ. Int. 2014, 63, 114-120. [CrossRef] [PubMed]

2. Jallow, M.; Awadh, D.; Albaho, M.; Devi, V.; Thomas, B. Pesticide risk behaviours and factors influencing pesticide use among farmers in Kuwait. Sci. Total Environ. 2017, 574, 490-498. [CrossRef] [PubMed]

3. Damalas, C.A.; Eleftherohorinos, I.G. Pesticide exposure, safety issues, and risk assessment indicators. Int. J. Environ. Res. Public Health 2011, 8, 1402-1419. [CrossRef] [PubMed]

4. Wanwimolruk, S.; Kanchanamayoon, O.; Phopin, K.; Prachayasittikul, V. Food safety in Thailand 2: Pesticide residues found in Chinese kale (Brassica oleracea), a commonly consumed vegetable in Asian countries. Sci. Total Environ. 2015, 532, 447-455. [CrossRef] [PubMed]

5. Boxall, R.A. Post-harvest losses to insects-a world overview. Int. Biodeter. Biodegr. 2001, 48, 137-152. [CrossRef] 
6. Narayanasamy, P. Postharvest Pathogens and Disease Management; John Wiley \& Sons: New York, NY, USA, 2006.

7. Damalas, C.A. Understanding benefits and risks of pesticide use. Sci. Res. Essays 2009, 4, 945-949.

8. Abrol, D.P.; Shankar, U. Pesticides, food safety and integrated pest management. In Integrated Pest Management; Pimentel, D., Peshin, R., Eds.; Springer: Dordrecht, The Netherlands, 2014; pp. 167-199.

9. Hashemi, M.; Damalas, C.A. Farmers' perceptions of pesticide efficacy: Reflections on the importance of pest management practices adoption. J. Sustain. Agric. 2010, 35, 69-85. [CrossRef]

10. Schreinemachers, P.; Chen, H.; Nguyen, T.; Buntong, B.; Bouapaoe, L.; Gautam, S.; Le, N.; Pinn, T.; Vilaysone, P.; Srinivasan, R. Too much to handle? Pesticide dependence of smallholder vegetable farmers in Southeast Asia. Sci. Total Environ. 2017, 593-594, 470-477. [CrossRef] [PubMed]

11. Fishel, F.M. Pesticide Use Trends in the U.S.: Global Comparison; Florida Cooperative Extension Service, Institute of Food and Agricultural Sciences, University of Florida: Gainesville, FL, USA, 2007; p. 3.

12. Zhang, C.; Guanming, S.; Shen, J.; Hu, R. Productivity effect and overuse of pesticide in crop production in China. J. Integr. Agric. 2015, 14, 1903-1910. [CrossRef]

13. Chen, R.; Huang, J.; Qiao, F. Farmers' knowledge on pest management and pesticide use in Bt cotton production in China. China Econ. Rev. 2013, 27, 15-24. [CrossRef]

14. Hou, L.; Huang, J.; Wang, X.; Hu, R.; Xue, C. Farmer's knowledge on GM technology and pesticide use: Evidence from papaya production in China. J. Integr. Agric. 2012, 11, 2107-2115. [CrossRef]

15. Yang, P.; Iles, M.; Yan, S.; Jolliffe, F. Farmers' knowledge, perceptions and practices in transgenic Bt cotton in small producer systems in Northern China. Crop. Prot. 2005, 24, 229-239. [CrossRef]

16. Al-Zaidi, A.; Elhag, E.; Al-Otaibi, S.; Baig, M. Negative environment and the farmers' awareness in Saudi Arabia: A case study. J. Anim. Plant Sci. 2011, 21, 605-611.

17. Idris, A.; Rasaki, K.; Folake, T.; Hakeem, B. Analysis of pesticide use in cocoa production in Obafemi Owode local government area of Ogun State, Nigeria. J. Biol. Agric. Healthc. 2013, 3, 1-9.

18. Mattah, M.; Mattah, P.; Futagbi, G. Pesticide application among farmers in the catchment of Ashaiman irrigation scheme of Ghana: Health implications. J. Environ. Public Health 2015, 2015, 547272. [CrossRef] [PubMed]

19. Mengistie, B.; Mol, A.; Oosterveer, P. Pesticide use practices among smallholder vegetable farmers in Ethiopian Central Rift Valley. Environ. Dev. Sustain. 2017, 19, 301-324. [CrossRef]

20. Wang, W.; Jin, J.; He, R.; Gong, H. Gender differences in pesticide use knowledge, risk awareness and practices in Chinese farmers. Sci. Total Environ. 2017, 590-591, 22-28. [CrossRef] [PubMed]

21. Khan, M. Adverse health effects, risk perception and pesticide use behavior: Evidence from Pakistan. MPRA 2009. Available online: http:/ / mpra.ub.uni-muenchen.de/16276/ (accessed on 15 July 2009).

22. Cameron, P. Factors influencing the development of integrated pest management (IPM) in selected vegetable crops: A review. N. Z. J. Crop Hortic. Sci. 2007, 35, 365-384. [CrossRef]

23. Ngowi, A.; Mbise, T.; Ijani, A.; London, L.; Ajayi, O. Pesticides use by smallholder farmers in vegetable production in Northern Tanzania. Crop Prot. 2007, 26, 1617-1624. [CrossRef] [PubMed]

24. Damalas, C.A.; Koutroubas, S.D. Determinants of farmers' decisions on pesticide use in oriental tobacco: A survey of common practices. Int. J. Pest Manag. 2014, 60, 224-231. [CrossRef]

25. Plianbangchang, P.; Jetiyanon, K.; Wittaya-areekul, S. Pesticides use patterns among small-scale farmers: A case study from Phitsanulok, Thailand. Southeast Asian J. Trop. Med. Public Health 2009, 40, 401-410. [PubMed]

26. Zyoud, S.H.; Sawalha, A.F.; Sweileh, W.M.; Awang, R.; Al-Khalil, S.I.; Al-Jabi, S.W.; Bsharat, N.M. Knowledge and practices of pesticide use among farm workers in the West Bank, Palestine: Safety implications. Environ. Health Prev. Med. 2010, 15, 252-261. [CrossRef] [PubMed]

27. Fan, L.; Niu, H.; Yang, X.; Qin, W.; Bento, C.; Ritsema, C.; Geissen, V. Factors affecting farmers' behaviour in pesticide use: Insights from a field study in northern China. Sci. Total Environ. 2015, 537, 360-368. [CrossRef] [PubMed]

28. Xu, R.; Kuang, R.; Pay, E.; Dou, H.; Snoo, G. Factors contributing to overuse of pesticides in western China. Environ. Sci. 2008, 5, 235-249. [CrossRef]

29. Togbé, C.; Zannou, E.; Vodouhê, S.; Haagsma, R.; Gbèhounou, G.; Kossou, D.; Van Huis, A. Technical and institutional constraints of a cotton pest management strategy in Benin. NJAS-Wagen. J. Life Sci. 2012, 60-63, 67-78. [CrossRef] 
30. Konradsen, F.; Hoekb, W.; Cole, D.; Hutchinson, G.; Daisley, H.; Singh, S.; Eddleston, M. Reducing acute poisoning in developing countries-options for restricting the availability of pesticides. Toxicology 2003, 192, 249-261. [CrossRef]

31. Abdollahzadeh, G.; Sharifzadeh, M.S.; Damalas, C.A. Motivations for adopting biological control among Iranian rice farmers. Crop Prot. 2016, 80, 42-50. [CrossRef]

32. Abdollahzadeh, G.; Sharifzadeh, M.S.; Damalas, C.A. Perceptions of the beneficial and harmful effects of pesticides among Iranian rice farmers influence the adoption of biological control. Crop Prot. 2015, 75, 124-131. [CrossRef]

33. Oluwole, O.; Cheke, R. Health and environmental impacts of pesticide use practices: A case study of farmers in Ekiti State, Nigeria. Int. J. Agric. Sustain. 2009, 7, 153-163. [CrossRef]

34. Hair, J.S.; Black, W.C.; Babin, B.J.; Anderson, R.E.; Tatham, R.L. Multivariate Data Analysis, 7th ed.; Pearson Education Limited: Essex, UK, 2013.

35. Nunnally, J.C. Psychometric Theory; McGraw-Hill: New York, NY, USA, 1978.

36. Adejumo, O.; Ojoko, E.; Yusuf, S. Factors influencing choice of pesticides used by grain farmers in southwest Nigeria. J. Biol. Agric. Healthc. 2014, 4, 31-38.

37. Aktar, M.; Sengupta, D.; Chowdhury, A. Impact of pesticides use in agriculture: Their benefits and hazards. Interdiscip. Toxicol. 2009, 2, 1-12. [CrossRef] [PubMed]

38. Tijani, A.; Sofoluwe, N. Factors determining the extent of pesticide use in Nigerian farms. J. Agric. Econ. Dev. 2012, 1, 1-9.

39. Williamson, S.; Ball, A.; Pretty, J. Trends in pesticide use and drivers for safer pest management in four African countries. Crop Prot. 2008, 27, 1327-1334. [CrossRef]

40. Hashemi, M.; Rostami, R.; Hashemi, M.; Damalas, C.A. Pesticide use and risk perceptions among farmers in southwest Iran. Hum. Ecol. Risk Assess. 2012, 18, 456-470. [CrossRef]

41. Karamidehkordi, E.; Hashemi, A. Farmers' knowledge of integrated pest management: A case study in the Zanjan province in Iran. Paper Presented in the Innovation and Sustainable Development in Agriculture and Food Symposium, (ISDA 2010), Montpellier, France, 28 June-1 July 2010.

42. Lekei, E.; Ngowi, A.; London, L. Farmers' knowledge, practice and injuries associated with pesticides exposure in rural farming villages in Tanzania. Public Health 2014, 14, 1-13. [CrossRef] [PubMed]

43. Ngowi, A. A study of farmers' knowledge, attitude, and experience in the use of pesticides in coffee farming. Afr. News. Occup. Health Saf. 2003, 13, 62-64.

44. Selvarajah, A.; Thiruchelvam, S. Factors affecting pesticide use by farmers in Vavuniya district. Trop. Agric. Res. 2007, 19, 380-388.

45. Talukder, A.; Sakib, M.; Islam, M. Determination of influencing factors for integrated pest management adoption: A logistic regression analysis. Agrotechnology 2017, 6, 163-166.

46. Khan, M.; Damalas, C.A. Factors preventing the adoption of alternatives to chemical pest control among Pakistani cotton farmers. Int. J. Pest Manag. 2015, 61, 9-16. [CrossRef]

47. Alam, M.; Haque, M.; Islam, M.; Hossain, E.; Hasan, S.; Hasan, S.; Hossain, M. Comparative study of integrated pest management and farmers practices on sustainable environment in the rice ecosystem. Int. J. Zool. 2016, 2016, 7286040. [CrossRef]

48. Rosenstock, I. Historical origins of the HBM. Health Educ. Monogr. 1974, 2, 1-8. [CrossRef]

49. Ecobichon, D.J. Pesticide use in developing countries. Toxicology 2001, 160, 27-33. [CrossRef]

50. Feola, G.; Gallatic, J.; Binder, C. Exploring behavioural change through an agent oriented system dynamics model: The use of personal protective equipment among pesticide applicators in Colombia. Syst. Dyn. Rev. 2011, 28, 69-93. [CrossRef]

51. Damalas, C.A.; Abdollahzadeh, G. Farmers' use of personal protective equipment during handling of plant protection products: Determinants of implementation. Sci. Total Environ. 2016, 571, 730-736. [CrossRef] [PubMed]

52. Sharifzadeh, M.S.; Damalas, C.A.; Abdollahzadeh, G. Perceived usefulness of personal protective equipment in pesticide use predicts farmers' willingness to use it. Sci. Total Environ. 2017, 609, 517-523. [CrossRef] [PubMed]

53. Wilson, C.; Tisdell, C. Why farmer continue to use pesticides despite environmental, health and sustainability cost. Ecol. Econ. 2001, 39, 449-462. [CrossRef] 
54. Yilmaz, H. Analysis in terms of environmental awareness of farmers' decisions and attitudes in pesticide use: The case of Turkey. Bulg. Chem. Commun. 2015, 47, 771-775.

55. Damalas, C.A.; Georgiou, E.B.; Theodorou, M.G. Pesticide use and safety practices among Greek tobacco farmers: A survey. Int. J. Environ. Health Res. 2006, 16, 339-348. [CrossRef] [PubMed]

56. Atreya, K. Pesticide use knowledge and practices: A gender differences in Nepal. Environ. Res. 2007, 104, 305-311. [CrossRef] [PubMed] 